\title{
THE ROLE OF PRIVATE ENTERPRISE IN WATER RESOURCES DEVELOPMENT
}

\author{
Roy E. HUfFMAN*
}

The problem of private-public relationships and responsibilities in the development, control, and use of the natural resources of the United States has provided the setting for much disagreement regarding acceptable national policy. Most of the argument over the appropriate role of private enterprise in water resources development, unfortunately has involved a maximum of emotion and partisan politics and a minimum of factual analysis. Of necessity, this paper too, will be lacking both in citations of other writings on the subject and in references to studies of the private-public aspects of specific resource development situations. But in a paper written on the same general problem several months ago, this writer referred to his work as "something of a pioneering effort"; ${ }^{1}$ and the situation has not since changed.

Currently, the private-public controversy is almost entirely an argument regarding the Eisenhower Administration's "partnership" policy for water resource development. The argument is more restricted, however, than the broad problem of public water policy would suggest. The proponents of the partnership policy are concerned, in most cases, only with its relationship to the development of hydroelectric power facilities. They refer to the partnership power policy. It is this restricted viewpoint that has been the focus of any discussion and analysis of the role of private enterprise in water resources development. Thus, in commenting on the Hell's Canyon controversy, this writer noted that "the discussion has revolved almost entirely around a comparison of the generating capacity of the alternative proposals vs. the construction costs of the alternative proposals" and suggested that "it seems reasonable to assume some differences would exist with respect to flood control, navigation, recreation and other public benefits and costs."

It appears, however, that the Eisenhower Administration is finding it necessary to broaden its viewpoint with respect to water resources policy. In discussing the extent to which Secretary of the Interior Fred A. Seaton is modifying the Hell's

* B.S. 1938, Montana State College; M.S. 1939, University of Maryland; Ph.D. 1952, University of Wisconsin. Professor of Agricultural Economics and Economics, and Chairman of the combined Departments of Agricultural Economics and Rural Sociology, and Economics and Sociology, Montana State College. Economist, Great Plains Water Conservation and Utilization Program, United States Department of Agriculture, I939-42. Consultant, President's Missouri Basin Survey Commission, 1952, and Task Force on Water Resources and Power of the United States Commission on Organization of the Executive Branch of the Government, i954. Author, Irrigation Development and Public Water Policx (I953), and many articles, research bulletins, and special reports in the field of public water policy.

'Huffman, Economic Implications of the Partnership Policy in Water Resources Development, 38 J. Farm. Econ. 1269, 1270 (1956).

${ }^{2} I d$. at 1271 , I272. 
Canyon position taken by former Interior Secretary Douglas McKay, Time Magazine commented: ${ }^{3}$

Though Seaton, like McKay, holds to the Eisenhower concept of private-public partnership in river development, he takes a broader view of what can be accomplished. Studying the private low dams that McKay favored, Seaton noted that they offered only limited flood control, failed therefore to achieve full development of the Snake River's potential. One high dam ... would generate more power and provide more flood control than two McKay-type low dams. ...

It is widely recognized that public policy for water is a national problem of major proportions and pressing significance. Peter F. Drucker illustrated the importance of the problem when he concluded a series of four articles under the overall title of "America's Next 20 Years" with a listing of the eleven most important policy issues facing the United States in the next twenty years. ${ }^{4}$ First on the list was the matter of public policy relating to the water resources problem.

In an attempt to present a complete analysis of a complex problem, this paper will be divided into four major parts. The first will present an historical perspective of the private-public relationships in past resources development in the United States. The second will discuss the requisites of an adequate national water policy to meet the growing demands of the nation. The third will analyze the "partnership" policy with respect to its abilities to meet future requirements. And the fourth will outline this writer's views on the role of private enterprise in the development of land and water resources.

\section{I}

\section{Private Enterprise in Past Resources Developarent}

The idea that private enterprise should function as a "partner" in the development of natural resources is not new. Throughout the history of this nation, private enterprise and public effort have collaborated in the development and use of land and water resources. This sort of an approach has been the accepted procedure as the vast land areas were settled and developed. This writer has suggested in more detail elsewhere that the major goal of resource development is to increase the capacity of the resource base to support private enterprise. ${ }^{5}$ It cannot be otherwise in a capitalistic economy. Thus, the federal government has sponsored programs and policies designed to improve the usability of the natural resources of the nation for private enterprise. Public programs to develop hydroelectric power and construct irrigation and drainage projects are not too far removed from our historical experience wherein the federal government subsidized canals and wagon roads, made

'Time, Feb. 25, x957, p. 25, col. 3.

The Coming Labor Shortage, Harper's Magazine, March 1955, p. 27; The Promise of Automation, id., April 1955, p. 41; The New Tycoons, id., May I955, p. 39; Eleven Coming Issues in Politics, id., Junc 1955, p. 52.

"Huffman, The Water Resource Problem, in Farm Foundation, Natjonal Conference on INcreasing Understanding of Public Problems and Policies 35 (1955). 
land grants to the railroads, and provided free public land to private enterprisers of all kinds.

Early water resources development was concerned with transportation through canal building and rivers and harbors improvement, and with agriculture through irrigation and drainage. The transportation facilities involved a large proportion of public activity from the beginning, but the early attempts to expand agriculture through water resources development was based to a considerable extent on private enterprise. Those interested in growth of the irrigated areas became skeptical at an early date regarding the ability of private enterprise to do the job, however, and began to push for public programs. Public policy fluctuated among public subsidy for private development, development by the states, and development by the federal government. Out of this situation, the Bureau of Reclamation evolved. In the meantime, the Army Corps of Engineers had become well established in water resources development in aid of transportation and for flood control.

Interest in the multiple-purpose aspects of water resources development was evident at an early date. Many early water projects presented opportunities for use other than the one purpose recognized in the original plans and construction. The actual multiple-use features of projects, however, were largely incidental and accidental. Limited quantities of hydroelectric power occurred as a by-product of irrigation and flood-control projects, but there was no stated policy of government participation. Muscle Shoals on the Tennessee River was probably the first project to be discussed in the multiple-purpose context, but the Boulder Canyon Project (Hoover Dam) was the first development authorized as a truly multiple-purpose project.

The concept of multiple-purpose development of resources expanded from initial application to individual projects to the development of entire river basins. Anshen and Wormuth note this evolutionary process beginning with Muscle Shoals:

The project was one of the most celebrated political footballs of the r920's. Farm groups argued for a long-term lease of the facilities to private operators who would manufacture fertilizer. The power industry favored a lease for private power generation. The proponents of public ownership wanted the government to operate the facilities. While these issues were in debate, the scope of the problems involved was being steadily enlarged. The operation of the facilities for the generation of power was being urged as one part of a coordinated program that would embrace navigation, irrigation, flood control, and reforestation, amounting to a program for the economic and social rehabilitation of the entire Tennessee Valley area.

The Tennessee Valley is known throughout the world as an example of comprehensive development of land and water for multiple uses. The idea of comprehensive development of resources has been carried into the other great river basins of the nation, but without the coordinated organizational structure of the Tennessee Valley Authority. The attempt to establish valley authorities in other regions reached its peak in 1945 , with the introduction of an omnibus authority act which

- Melvin anshen and Francis D. Wormuth, Private Enterprise and Public Policy 353-54 (1954). 
would have divided the continental United States among nine authorities. ${ }^{7}$ The bill was not passed, and, although valley authorities continue to be discussed, other forms of organizational structure have come to the fore in various attempts to secure the coordinated development and operation which has been achieved in the Tennessee Valley. Baumhoff has noted in his study of the Missouri Basin that the coordinated development of the TVA is generally accepted as necessary but that many persons are on record as opposed to the valley-authority type of organization. He suggests that the answer for the Missouri Basin may be a "Missouri Valley Anti-Authority Authority."

Much of the opposition to the Tennessee Valley Authority is related to the privatepublic power argument. This is true also of opposition to the establishment of valley authorities in other regions. Although public power development has been carried on in other river basins, such as the Columbia, without a valley authority, one governmental organization has not been dominant as in the Tennessee Valley. The implications of comprehensive development, including the basic interrelationships of land and water, are generally ignored or not understood.

The narrow viewpoint of one spokesman for private enterprise in water resources development is evident in the five lectures given by Ben Moreell at the University of Chicago. ${ }^{9}$ Admiral Moreell is retired from the Civil Engineer Corps, United States Navy, and was Chairman of the Task Force on Water Resources and Power of the Second Hoover Commission. His lectures include virtually no mention of multiple use of resources or of multiple-purpose projects. Admiral Moreell is disturbed that foreign engineers and administrators want to see the TVA. He writes: ${ }^{10}$

Forgotten is the fact that Hoover, Shasta, Grand Coulee, Fort Peck . . . are among the highest and largest in the world and they were built by the Bureau of Reclamation or the Corps of Engineers, not by a valley authority.

There is no recognition of the fact that foreign visitors are interested in the TVA as an attempt at comprehensive and total development of resources; Admiral Moreell rather assumes the typical engineering viewpoint that accomplishment is measured by the "highest and largest" dam. On the basis of such a criterion, he should be an advocate of the high dam at Hell's Canyon, but it is obvious he is not. Admiral Moreell concludes that public activity in hydroelectric power development is "all wrong." ${ }^{11}$

Lack of understanding of the fundamentals involved is further evident in Admiral Moreell's skepticism regarding watershed management. He is probably on firm ground when he questions the campaign for "an upstream small-dams approach as a complete alternative to any other measures for flood control." His contention that there is little evidence of the value of land treatment and watershed manage-

\footnotetext{
${ }^{\tau}$ See Roy E. Huffman, Irrigation Development and Public Water Policy i68-69 (1953).

${ }^{8}$ Richard G. Baumhoff, The Dammed Missouri Valley 291 (1951).

${ }^{9}$ Ben Moreell, Our Nation's Water Resources-Poltcies and Politics (1956).

${ }^{10}$ Id. at 85 .

${ }^{11}$ Id. at 188 .
} 
ment because of the "marked failure of the Department of Agriculture to provide data for objective analysis by disinterested engineers and scientists" and his statement that the advocates of land treatment and watershed management "merely want Federal funds placed in the hands of other agencies for other kinds of works," however, are not so well founded. ${ }^{12}$ These views conform to the widespread belief that all worthwhile economic activity can be determined by the private-profit motive and that no benefits exist unless they can be measured in dollars and cents. The problem of appropriate recognition of nonmonetary benefits of development is crucial in the private-public controversy.

These lectures have been discussed in some detail because they set forth clearly the viewpoint at one extreme. Somewhere between this viewpoint and the other extreme of complete public domination is to be found the answer to the role of private enterprise in water resources development.

II

\section{The Need for an Adequate National Water Policy}

The growing demand for water in the United States is focusing attention on the importance of an adequate national water policy. The increasing volume of water required is a result of two factors: population growth and greater per capita consumption.

The United States is experiencing one of the periods of most rapid population growth in its history and is now one of the fastest-growing nations in the world. There is some evidence that population experts consider the high birth rate to be a temporary phenomenon, ${ }^{13}$ but each year for the past decade the number of births in the United States has continued to climb. For the past three years, the number of births has exceeded $4,000,000$ each year. ${ }^{14}$ The result in total population has been startling. In mid-February this year, the Bureau of the Census estimated that the population of the United States had reached $170,000,000 .{ }^{15}$ This compares with a 1947 forecast prepared by Whelpton for the Bureau of the Census which projected the population to $156,775,000$ in 1960 and $169,801,000$ in $1975 .^{16}$ As recently as 1952 , the President's Materials Policy Commission assumed 193,000,000 people in the United States by $1975 .^{17}$ Present trends indicate, however, that we will approximate that figure by 1965 . Current estimates project a population of $228,500,000$ in 1975 on the basis of the present birth rates. ${ }^{18}$ These figures alone are impressive, but the

${ }^{12} I d$. at I $\mathrm{II}^{\mathrm{I}}$.

13 The population projections issued by the Bureau of Census in I953 included a series that assumed a decline in the birth rate to prewar levels by 1960 , with fertility remaining constant at that level to 1975 . See U.S. Bureau of the Census, Dep't of Commerce, Current Population Reports: Population Estrimates (Series P-25, No. 78, 1953).

"Sce U.S. Bureau of the Census, Dep't of Commerce, Current Population Reports: Population Estimates (Series P-25, No. 153, 1957).

${ }^{16} \mathrm{Sec}$ Associated Press release, Feb. 15, 1957.

${ }^{20}$ P. K. Whelpton, Forecasts of the Population of the United States $4 \mathrm{I}$ (1957).

${ }^{17}$ I President's Materials Policy CoMm'n, Resources for Freedom 7 (1952).

${ }^{18}$ See U.S. Bureau of the Census, Dep't of Commerce, Current Population Reports: Populatton Estrmates (Series P-25, No. 123, 1955). 
impact on water resources is not fully evident until they are coupled with per capita water requirements.

The population projections noted above can be thought of roughly as involving a one-third increase in population in the twenty years ending in 1975 . At the same time, we are told that the nation's water requirements in 1975 will be double the amount used now. ${ }^{19}$ This large increase in per capita use is a result of greater demand in all uses-domestic, industrial, agricultural, and recreational. The scope of the water problem facing the nation, and its complexity, thus come into clearer focus when viewed in relation to population growth and per capita use. It is evident that the contribution to be made by private enterprise in meeting the problem and the extent of public responsibility are important to the future of the United States.

Concern regarding the water resources problem has been most evident in those locations where it is obvious that water is a limiting factor in economic growth. California and some other states are particularly concerned with this phase of the problem. Civilizations have flourished on the basis of the development and use of their water resources. The remains of great water facility structures scattered over the face of the earth attest to the importance of water resources to the growth and stability of an economy. Water resources development was significant in the existence of such civilizations as Babylonia and in the long history of Egypt, China, and India. The nations which flourished in the Mediterranean area, including Rome, Carthage and early Spain, leaned heavily on the development of their water resources. Prehistoric people in the Americas, including the Incas of South America and the Pueblo Indians of our own states of Arizona and New Mexico, reached an advanced stage of water development and use. It seems obvious that water resources have been basic to the growth of many of the great civilizations of the past. We do not know why many of these nations vanished from the scene, but there is evidence that at least some of them failed because their water resources failed. In some instances, it appears that the civilizations broke down because of a failure to recognize the basic interrelationship of land and water.

Failure to recognize the critical importance of water as a basic resource is not a state of mind which man has outgrown. It has been a long and difficult process in this country to secure an adequate appreciation of the problem, and the battle is not yet won. There are still many people who seem to ignore the facts around them and feel that water should be a free good, or at least nearly so. This lack of understanding of the scarcity of water relative to demands is the key to much of our problem in securing an adequate recognition and understanding of the water resources problem. Then, too, there is the idea held by some that if you ignore a problem, it will somehow disappear.

It seems rather obvious, then, that the federal government has a major obligation to formulate and carry out a long-range policy for water resources development in the United States. I believe that the federal government has a responsibility in the

\footnotetext{
${ }^{19}$ Presidential Advisory Comm. on Water Resources Policy, Water Resources Policy 5 (1955).
} 
resources field akin to its responsibility for national defense. A nation which loses or outruns its resource base is doomed to extinction or a permanently low level of living. The Administration which took office in 1952 , however, proposed to reduce federal responsibility for the protection and development of natural resources and to leave much of the responsibility to private enterprise. It has been largely as a result of the views of individual citizens as expressed at the ballot box that the federal government now appears to be resuming its responsibilities for insuring an adequate national water policy for today's population as well as generations yet unborn. It would appear to be highly significant that the disapproval of a policy which reduced federal responsibility in the resources field was concentrated in the Columbia basin, where public development of water resources had provided the foundation for noteworthy expansions in private enterprise.

The manner in which private enterprise and public effort should be combined into a national water policy remains the important question. It cannot be assumed that the question has been answered merely because we are said to be operating under a "partnership" policy. As noted earlier, resources development in the United States has always involved varying degrees of private and public effort. The heart of the problem is concerned with the proportions of private and public participation necessary to insure the future of the nation.

The federal government has given considerable attention to the water resources problem. Over the years, the legislative and executive branches of government have established a number of study commissions and committees on water resources. The six-year period, 1949-55, saw the release of reports from the First Hoover Commission (1949) ${ }^{20}$ the President's Water Policy Commission (1950), ${ }^{21}$ the President's Missouri Basin Survey Commission (1953), ${ }^{22}$ the Second Hoover Commission (1955), ${ }^{23}$ and the Presidential Advisory Committee on Water Resources Policy (1955) ${ }^{24}$ A mass of data and many recommendations are available. Future water policy has not been determined at state, regional, or national levels. The importance of the problem, however, has been thoroughly established and documented.

\section{III}

\section{Adequacy of the Partnership Policy}

At this point, it appears appropriate to evaluate the "partnership" policy which emphasizes the joint participation of public agencies and private enterprise in the development of the nation's resources. The partnership policy must be analyzed mainly from the standpoint of intent rather than performance. There is little, if any,

\footnotetext{
${ }^{20}$ U.S. Comm's on Organization of the Executive Branch of the Governatent, Task Force Report on Water Resources Projects (1949).

${ }^{21}$ President's Water Resources Policy Coma's, A Water Policy for the American People (1950).

${ }_{22}$ Missouri Basin Survey Commin, Missouri: Land and Water (1953).

${ }^{23}$ U.S. Comin on Organization of the Executive Branch of the Government, Report (Vol. I, WATER Resources AND POWER) (1955).

${ }^{24}$ Prestdential Advisory Comim. on Water Resources Policy, op. cit. stipra note ig.
} 
experience to which one can turn in the way of functioning projects or programs demonstrating the partnership policy in action.

The Eisenhower Administration's partnership policy for natural resources development has been outlined in a number of places. Three points are quoted here:

(r) . . I I believe that the Nation must adhere to three fundamental policies: first, to develop, wisely use, and to conserve basic resources from generation to generation; second, to follow the historic pattern of developing these resources primarily by private citizens under fair provisions of law, including restraints for proper conservation; and third, to treat resource development as a partnership undertaking-a partnership in which the participation of private citizens and State and local government is as necessary as is Federal participation. ...

.... The Federal Government must shoulder its own partnership obligations by undertaking projects of such complexity and size that their success requires Federal development. $^{25}$

(2) One of the primary considerations in establishing the partnership power policy has been the need for an adequate supply of power.... Here is where our power partnership policy enters. The idea is very simple. It is based on the concept of individual initiative with government cooperation. Because of the large expenditures required to assure that our power needs will be fully met, this department has encouraged state and local public bodies and private organizations to supply their own power needs and to share with the Federal Government in the development of our water resources. Thus, the Federal Government will be in a better position to contribute toward the cost of those necessary projects which, because of size or complexity, are beyond the capability of state or local groups to finance or which provide benefits of a broad public nature.20

(3) In our concept local groups are those people with legitimate interests in developing the resources of an area. In this term we include: private persons, state and other political subdivisions, public power districts, irrigation districts, public utility districts, corporations, privately-owned public utilities, or other responsible non-Federal groups regional in character. If they are financially capable of developing the natural resources of an area, we are willing to be partners with them or, if able, they should proceed alone. We do insist that projects will proceed in a comprehensive manner to assure maximum development of our resources for multiple uses including power, fish and wildlife, recreation, municipal and industrial water, irrigation and other beneficial uses. ${ }^{27}$

The above statement suggests a greater degree of federal responsibility in resources development under the partnership policy than others concerned with the policy have recognized. If this statement by the President is taken as the charter for the partnership policy, it is quite possible to give adequate consideration to the public interest and the long-run needs of the nation. In theory, the partnership policy is a sound and workable plan. As interpreted for practical application by those called upon to administer it, however, much of the generally accepted area of federal responsibility is abandoned and the policy becomes one of expanding hydroelectric power develop-

${ }^{25}$ Eisenhower, The State of the Union, Ior Cong. REc. I22 (1955).

${ }^{26}$ Statement of Secretary of the Interior Douglas McKay to the House Committee on Interior and Insular Affairs, March 30, 1955, as reported in Evolution of Power Policy, 34 Cong. Dic. 293, 294 (I955).

${ }^{27}$ Ibid. 
ment by private enterprise and largely ignoring the associated multiple uses of the resources involved.

President Eisenhower emphasizes in the partnership policy the federal responsibility for developing projects which, "because of size or complexity," are beyond the capability of state or local effort. If he had said, also, that the alternatives to federal development must be equivalent projects in terms of the benefits produced, the choice between private and public development would have been more clearly drawn. The apparent reversal of administration viewpoint with respect to Hell's Canyon, referred to earlier in this paper, confirmed the contention that the proposed private development is not an equivalent project. It is becoming daily more evident that the United States is not a nation of inexhaustible resources with the choice of using its resources wastefully or only partially. In the case of water, it will be necessary to make the most complete use possible of the available supply if we are to fill all of our requirements. In view of population growth, higher dietary levels, and the loss of good agricultural land to nonagricultural uses, the same may be true as well for land resources. Crop surpluses may turn out to be a temporary phenomenon in the history of the nation.

The partnership policy, as laid down by President Eisenhower, insists that "projects will proceed in a comprehensive manner to assure the maximum development of our resources for multiple uses including power, fish and wildlife, recreation, municipal and industrial water, irrigation and other beneficial uses." It is in relation to the complete development of resources on the basis of multiple uses that the application of the partnership policy appears weakest. There is little evidence that private enterprise is concerned with other than power generation and little indication that private enterprise understands the importance and complexities of multiplepurpose development. It is understandable that private enterprise would be interested in the uses which will produce revenue and not concerned with the uses producing nonmonetary benefits. The nonmonetary benefits arising from water involved in recreation, fish and wildlife, and flood control must be integrated, however, with the revenue-producing uses if the partnership policy is to be as effective as it should be. The simple solution would be to ignore the nonmonetary benefits, and even some of the less lucrative revenue-producing benefits, and concentrate on such a use as power generation. This procedure, however, would involve sizable losses to society in unrealized benefits. It should be noted, too, that the lost benefits would be those which are increasing in importance as a result of population growth, greater industrialization, shorter work weeks, more leisure, and a growing demand for recreational resources.

\section{IV}

Private Enterprise in Future Resources Development

Private enterprise operating within our democratic framework of government has been the most important factor in the development of the United States as we know 
it today. The challenge to private enterprise now is to make its contribution to the future resources development of the nation in such a way as to secure the maximum in benefits. This implies a recognition on the part of private enterprise of the broad range of the public interest in how the resources of the nation are developed, controlled, and used.

It is not necessary that the private-public relationship follow the same pattern in all resources development situations. Power resources are an example. Most industrial countries have developed their power resources under a system of public ownership. The United States has depended primarily on private ownership and public regulation. Unless private development of resources can meet the needs of the nation, it seems likely that regulation or outright public ownership may be expanded in the period ahead. There are many "in between" possibilities, however, in integrating private and public effort in power facilities. A private firm might retail power from public generating and distributing facilities. A private firm might own the retail facilities and the distribution lines while receiving power from a public dam and power house. A private firm might own the retail facilities, distribution lines, and the power house in a public dam. A private firm might build the dam and own all the facilities to the ultimate consumer. In the last case, the public could subsidize the private firm for the nonmonetary public benefits arising from the dam. Such an arrangement would make possible full multiple use of a resource situation on the basis of a private-public partnership.

If private enterprise is to meet its obligations in resources development, the leaders in the private companies have a further challenge facing them. In addition to adequate consideration of the multiple-use potentialities of individual structures, private enterprise must fit its developments into basin-wide management of resources. Just as multiple-purpose development of an individual structure will maximize the benefits of a particular site, so will comprehensive and integrated development of a river basin maximize the benefits of a river system. This is a complex problem, indeed. Basin-wide development and management of resources would not be simple if all the structures were publicly owned. The problem is highly complicated if some structures are owned by one or more private power companies, others are owned by federal, state, and local units of government, and watershed treatment and management occurs on both publicly and privately-owned lands.

The extent to which public development of resources expands and dominates the economic activity of the nation will be determined by private enterprise. If private enterprise demonstrates a willingness to develop and manage resources in the broad framework necessary to meet the rapidly expanding needs of a growing population, then private enterprise can be a dominant partner in the future of resources development, as it has been in the past. If not, the people themselves will insist that government, through regulation and demonstration, force private enterprise to adopt the same enlightened viewpoint toward natural resources as it now accepts with respect to human resources as a result of regulatory measures and government programs 
affecting wages and hours, working conditions, social security, and many other fringe benefits. It should be recognized that many private enterprisers, individually or in partnership with public programs, are operating in this enlightened framework.

It cannot be denied that public programs have demonstrated in a practical manner some of the theoretical concepts of resources development and use which were not accepted by private enterprise. For example, the Tennessee Valley Authority demonstrated conclusively the elasticity of demand for electrical energy. Anshen and Wormuth state the situation very well as follows: ${ }^{28}$

By showing that lower rates led to increased consumption which more than compensated for rate reduction, it stimulated expansion into new markets by privately owned utilites. This is a task which in all probability could have been performed only by public ownership. Public utilities are conservative, partly because of their monopoly position and partly because they know that in the long run, despite all their exertions, their earnings will be pretty largely limited by the regulatory authority to a fixed return on their valuation. The prospective rewards of innovation are much outweighed by the risks. Nor could a regulatory commission constitutionally compel a public utility to embark upon speculative rate reductions in the hope that the resulting increase in consumption would compensate for the lower selling price per power unit. Yardstick competition comes down in the end to the use of public "risk capital" to pilot the way for expansion of private enterprise.

In conclusion, then, this writer suggests that the maximum in combined private and public effort will be necessary to meet the needs of the nation's growing population and expanding economy in the next quarter of a century. The public has pretty well demonstrated its acceptance of public development of resources if private enterprise does not do the job. It appears that the role of private enterprise in water resources development in particular and resources development in the broadest framework will be largely determined by the record of performance made by private enterprise.

${ }^{28}$ ANSHEN AND WORMOTH, op. cit. supra note 6, at 288. 